\title{
THE STRUGGLE OF THE PEOPLE'S PARTY OF BRUNEI IN MALAYSIA, 1973-1979
}

\author{
Habid's Buhigiba bin Mohamad Bustamam, ${ }^{*}$ Suffian Mansor \& \\ Mohd. Bin Samsudin \\ *First author \\ The School of History, Politics and International Affairs, \\ Universiti Kebangsaan Malaysia \\ (habids@gmail.com,smansor@ukm.edu.my, aasw@ukm.edu.my) \\ DOI: https://doi.org/10.22452/jati.vol24no1.3
}

\begin{abstract}
This article discusses the revival of the People's Party of Brunei (PRB) between 1973 and 1979 and its impact on Brunei's security. Most early writing on PRB focused on the early years of the growth of nationalism in Brunei. When rebellion broke out in Brunei in 1962, the PRB was banned. However, works concerning the development of the second PRB between 1973-1979 rarely received attention. There are many stories about the escape from the Berakas Detention Camp by PRB members without a recognised source. The primary purpose of this study is to explain the reasons for PRB being revived in Malaysia in 1973. In addition, this study is an attempt to explain the development and achievements of PRB from 1974-1976. This study will also analyze the main reason behind PRB's failure and the end of their struggle in 1979. The findings show that the success of the PRB revival is through the support of the Government of Malaysia. However, the Government of Malaysia's support for the PRB was occasioned by the conflict between Brunei and Malaysia over the issue of Limbang. A change in leadership in Malaysia ended the PRB struggle, along with the intervention of the British Government to resolve the problems of both countries. Brunei's independence in 1984 ended the struggle of the PRB. This study uses a qualitative method with historical research that focuses on the primary resources available in local archives.
\end{abstract}

Keywords: PRB revival; British intervention; Hussein Onn; Limbang; Malaysia's support

\section{Introduction}

The People's Party of Brunei (PRB) was founded on 22 January, 1956 (Suara Rakyat, 1957). During the District Council elections in August 1962, PRB won 54 
out of 55 contested seats. When PRB became involved in Brunei's rebellion on 8 December, 1962, PRB was banned and disappeared from Brunei's political landscape. The indirect effect of the rebellion was that Brunei had withdrawn from joining the Federation of Malaysia (Harun Abd Majid, 2007). After the formation of Malaysia in 1963, Sir Omar Ali (Sultan Omar Ali Saifuddin III abdicated the throne on 4 October, 1967, and was succeeded by his son, Hassanal Bolkiah), who sought to regain the Limbang District from the Government of Malaysia. The Government of Malaysia was under tension when Sir Omar Ali increased the pressure together with the claim of Sabah's territory by the Philippine Government (Norizan Kadir, 2017). Increasing pressure on the Malaysian Government caused Raja Azlan to be very sympathetic to the struggle of the PRB to take action against the Berakas Detention Camp on 12 July 1973 (FCO, 1973a). The detention of detainees was also assisted by Mahmud Morshidi Othman (2018), who also had a family relationship with A.M. Azahari leader of PRB. The main purpose of this study is to explain the revival of PRB in Malaysia in 1973. Besides, this study also tries to explain the achievement and development of PRB during 1974-1976. This study will also analyze the main reason behind PRB failure and ended the struggle in 1979.

On 12 July 1973, eight PRB political detainees fled to Kuching from Limbang (Said Haji Mohidin, 2010). The role of the Malaysian Government is quite unclear, but Coster's investigation (Head of the Special Branch of Brunei) and reports issued by Peter Gautrey in Brunei openly accused the involvement of Malaysia in the Berakas Detention Camp (BHC Brunei, 1973b). However, the British Government rejected an accusation by the State of Sarawak and Malaysia concerning an attempt to free the detainees from Berakas Detention Camp, although Sir Omar Ali defended his allegations (FEER, 1973). When Datuk Abdul Rahman Ya'kub (after this Rahman Ya'kub) suggested political asylum, the Federal Government had no choice but to cooperate not to overthrow the Chief Minister of Sarawak (Bolt, 1973a). At the same time, the act of granting political asylum was in line with the "UN Convention on Refugees 1951." At the same time, if the Malaysian Government was to insist on repatriating all the refugees, they would face international criticism, especially from the United Nations (Flower, 1973).

The Brunei Government requested that the Malaysian Government handover all the detainees, but there was no response (Gautrey, 1973). The British Government refused to intervene because the Government of Brunei also had a similar history of protecting two Filipino refugees who escaped to Brunei (Hickman, 1973c). The dispute over the Limbang matter made it difficult for Brunei to hold discussions with the Malaysian Government on the issue of 
refugees. The British Government was also trying to minimise its involvement as this case also involved Zaini Ahmad and a PRB member, who had been detained without trial for more than ten years, which was criticised by Amnesty International. The extradition process also faced problems arising under Section 4, the Fugitive Offenders Act 1967, "... no person can be extradited for an offence of a political character." This political offence clause became an obstacle to any extradition request made due to the retired PRB member is a political prisoner in Brunei (Hickman, 1973b).

The Government of Malaysia agreed to grant political asylum to all PRB refugees on condition that they did not engage in political affairs and continue to live in Sarawak (BHC Kuala Lumpur, 1973a). They were also informed that if the Government of Brunei wanted to extradite all political refugees, they could do so through the British Government channel. The British High Commissioner in Kuala Lumpur was aware that the Malaysian Government is innocuous about the action to take. However, the granting of political asylum was the most appropriate choice. At the same time, the British Government refused to release the news of the PRB refugee to prevent this issue became viral in the two countries (FCO, 1973b). Looking at the situation between the two countries that would have been hot, the Foreign Commonwealth Office advised British officer in Brunei to try to " $\ldots$ to minimise the risk of Sir Omar Ali using this incident as ammunition in his general campaign against Malaysia or in relation to Limbang specifically" (FCO, 1973c).

Since the beginning of the issue, the Malaysian Government was aware the granting aid and the status of political asylum to detainees would cause the issue of Limbang to heat up. Hence, Malaysian officials assumed that the increase in PRB activities would hopefully be able to divert the issue of Limbang in the relations between the two countries. At the same time, FCO officials tried to persuade the Government of Brunei that actions to expose Malaysia's role in the detention of PRB detainees would not have a positive impact on Brunei, because there was no evidence that the Malaysian Government was involved. Similarly, political asylum to PRB members was obtained through the application process and was not proffered by the Malaysian Government. The Malaysian Government only formalised the application for political asylum by PRB refugees in Malaysia on 26 July 1973 (Bernama, 1973).

The news of PRB detainees from the Berakas Detention Camp was broadcast on radio in Brunei on the night of 25 July 1973, which named the Malaysian Government as being involved in the incident and having brought the detainees to Kuching (BHC Brunei, 1973a). The action of the Government of 
Brunei indicated that Malaysia's involvement in the event was very disturbing to the British Government, as Brunei's External Affairs were still under the British.

The accusation of Sir Omar Ali finally triggered a quarrel through the mass media between himself and the Chief Minister of Sarawak. However, Razali Ismail, Deputy Secretary-General of the Ministry of Foreign Affairs, saw Rahman Ya'kub's speech only as a spontaneous action to defend Sarawak's right to the Limbang District (Boldt, 1973a). In contrast to Ghazali Shafie, Home Minister of Malaysia saw that the issue of Brunei could affect the level of security in Malaysia if Indonesian Communist elements succeeded in influencing PRB and the people of Brunei (Johnston, 1973a). Malaysia's support for the PRB was not intended to overthrow Sir Omar Ali, but they were worried that an increase in Communist influence could be absorbed into PRB if left alone. Ghazali Shafie also assumed that the failure of the Communist movement in the early stages caused them to change the strategy by focusing specifically on gaining support from the Malays by manipulating dissatisfaction. This is why the Malaysian Government provided support to the PRB refugees to attract the attention of the dissatisfied Brunei people to continue to support PRB instead of Communist elements (Johnston, 1973c). The views of Ghazali Shafie were somewhat different from the British officers' assessment, although they did not entirely reject these assumptions (Hickman, 1973a).

Since the PRB detainees left for Malaysia, police in Brunei found that there was a high increase in anti-government activities among former TNKU, government officer, and senior high school students in Brunei. The police saw the seriousness of the people's involvement as this also included military officers in the Royal Brunei Malay Regiment (Moffatt, 1973a). At the end of 1973, a rise of anti-government activity was seen from the borders of Brunei, namely Miri and Limbang. Coster's view of the atmosphere in 1973 was not anti-British, but it was more to Sir Omar Ali's personality, who lived in luxury while the people of Brunei faced a relatively high cost of living and lack of employment.

The British officers, too, found that it was quite hard to relate the citizens of Malaysia in regards to the incidents that have happened in Brunei and the borders of Sarawak. This is due to many Malaysian citizens working in Brunei, both in the oil and gas sector and government service. To deny Malaysia in helping PRB and Zaini cannot easily to be seen as a small matter, because as Ghazali Shafiee (Moffatt, 1973b) stated to A. Royale, "the Malaysians are getting reports from people (agents?) in Brunei and this could be two-way traffic." The British officers realised that the Malaysian Government's actions were due to their worry concerning Sir Omar Ali's actions in the District of Limbang. It is 
hence not surprising that after the detainees fled from the Berakas Detention Camp, the relationship had worsened.

The instability of the world oil prices since the Arab-Israel crisis of 1973 is seen to have led a few British officers towards realising the British should retain their force in Brunei. They, too, realised that they need to secure the protection of the British economy rather than acting only to cater to the needs of the Malaysian Government towards Brunei (Johnston, 1973b). Apart from that, the British advisors refused to offer help due to Sir Omar Ali always acting out of the specified field of power of affairs in Brunei (SWPD, 1973).

The Malaysia-Brunei relationship became more tense when Sir Omar Ali instructed his forces to monitor the entrance and exit between Miri to Limbang through Brunei. Police vehicles and Malaysia Armed Force that had to go through Brunei would be checked in detail (Moffat, 1973). All aircraft and ships transiting from Brunei to Malaysia would also be examined thoroughly to stop Malaysia from intervening in the safety issue in Brunei (BHC Kuala Lumpur, 1973b). The British Commissioner in Brunei objected to Sir Omar Ali's decision as they worried that the action would affect the British Government's image, as they were currently in charge of Brunei's defence affairs and foreign policy. At the end of 1973, if the British Advisors did not control the tension, it had the potential to worsen in tandem with their unwillingness to sit together to solve the matter. To avoid a more embarrassing crisis for the British Government internationally, the British officers realised that they would need to take action and play a more active role as an approach. In regard to concern about the PRB's activities in Malaysia, Ghazali Shafie promised that the Malaysian Government would be monitoring the movements of PRB's members in Malaysia so that they could not cause any political or safety problems in Malaysia and Brunei. Ghazali Shafie denied the allegations of involving Malaysian Government in the issue of escaping the PRB detainees. The action of the prison officers was seen to be an individual action that was not influenced by the Malaysian Government.

Worries of the movement by the PRB detainees in Malaysia worsened when there were initiatives made by PRB to organise a meeting with the Brunei students in a few of institutions in Malaysia to develop "Pertubuhan Pembebasan Rakyat Brunei" (Brunei Security Report, 1973). Although there were guarantees from Malaysian Government to curb PRB's activity towards students, however, it is deemed as pretty complicated for the Malaysian Government to monitor it effectively. Failure of the Malaysian Government to provide guarantees led to Sir Omar Ali to take action by pulling out all Brunei's students that were studying in Malaysia, and some were sent to Singapore to further their studies. 


\section{Literature Review}

Most studies conducted on PRB focus on the early nationalism in Brunei, which was before 1962. The involvement of PRB in 1962's uprising has gained attention of researchers such as Zaini (1989), Mohamad Bolkiah (2007), Harun Abd Majid (2007), Mackie (1974) and Greg Poulgrain (2014). The book written by Zaini (1989) is pertinent, because it is the only record written by PRB members. However, Zaini focuses more on the early development of nationalism in Brunei before 1963. Harun Abdul Majid (2007) tried to examine how the imperialism, confrontation and oil led to the 1962 revolt. Mohamad Bolkiah's writing also focuses on the reasons behind the 1962 rebellion from his perspective. Mackie (1974) focuses on political issues in Indonesia and weaknesses in economic reforms that lead to confrontation. Poulgrain (2014) looked in depth into the origins rather than the evolution of the 1962 Brunei Revolt. Only an article written by Nani Suryani (2016) discussed the issue during the 70s, which is focused on Brunei's refusal to join the Federation of Malaysia as well as the Limbang conflict. However, the role of PRB between 1973-1979 was less noticeable. The development of PRB between 1973-1979 has not received the attention of local scholars because of resource constraints.

\section{Methodology}

This study uses a qualitative method in historical research that focuses on primary resources. Historical research was conducted through library and archival research by accessing primary sources at the National Archive of the United Kingdom, Tun Seri Lanang Library (UKM), The National Library of Malaysia, the Sarawak State Archive and the Sabah State Archive. The primary sources used in this research are the Foreign Commonwealth Office (FCO) files, which include the official channel for communication between the British High Commissioner in Brunei, Kuala Lumpur and FCO in London. Additionally, news and commentary articles from several newspapers such as Pelita Brunei, Utusan Malaysia, Sarawak Tribune, Bernama Report, The Borneo Bulletin, The Straits Times and Suara Rakyat have been used. The secondary sources include books and journal articles regarding the issues of PRB. The documents in this research are analysed through a historical method which needs a principle of criticism and proper criticism procedures as suggested by Bernheim and Seignobos (Jha, 2014: 108-109). 


\section{Analysis}

After fleeing from Brunei, PRB had two significant achievements: first, reshaping PRB outside Brunei and setting up a provocative strategy in Malaysia; and second, raise Brunei's independence issue to the international level, which led the United Nations to pressure the Government of Brunei to implement changes and reforms.

\section{PRB Activity in Malaysia}

After the situation stabilised, a meeting was held in Kuala Lumpur by the PRB members to reinvite Azahari to lead PRB in Malaysia (Osman Latif, 2017). For the PRB members, Azahari's effort before 1962 led to him still being the General Leader of PRB. Therefore, Yassin Affendi was sent to Jakarta to announce PRB decisions in Kuala Lumpur to Azahari. Azahari's agreement to receive the decision of the PRB board members managed to fire up PRB's spirit in Malaysia starting in 1974.

Through the reformation of PRB in Malaysia, British officers were able to see that Malaysia had been taking tactical moves by supporting the PRB's international campaign indirectly, with the hope that Sir Omar Ali could initiate a new constitution and also political freedom. If the PRB international campaign succeeded, it would worsen the British Government's image due to the British officers' actions to defend Sir Omar Ali's actions by pressuring freedom of speech and the human rights in Brunei. Hence, J.K. Hickman (1973d) suggested that the agreement involving Britain in the Brunei affairs of defence and foreign affairs to be reexamined. Additionally, the British Government told their officers to avoid meeting any of Sir Omar Ali's principals in Brunei. In order to improve the roles of British officers, Hickman stresses out that British should be assertive towards Sir Omar Ali especially in regard to the revamp of the constitution and in helping the detainees to escape in 1962. This is part of the initiative so that Sir Omar Ali will adhere to the suggestions that were put forth by British Advisors together with other international agencies such as Amnesty International.

In early 1974, there was an increase in PRB activities by Zaini to force Sir Omar Ali to revamp the constitutional and to give more opportunity for the Brunei citizens in Brunei's administration through elections. Rahman Ya'kub also voiced the action of the people of Brunei to demand the independence and insult the selfish acts of Sir Omar Ali who was denying the will of the people of Brunei (Gautrey, 1974a). Rahman Ya'kub speech got strong support from the PRB members and TNKU, recommending that Brunei citizens declare Brunei's independence (PRB Document, 1974). However, from other aspects, Malaysia's support for PRB's fight was indirectly able to distract Sir Omar Ali's focus from 
the Limbang issue to Brunei's security issues. Sir Omar Ali's worries were proven during a meeting by the Security Council of Brunei on 4 March 1974, when he pleaded the British Government to use the Gurkha army that was in Brunei to help in preventing threats coming from Limbang. However, his application was rejected due to PRB being too insistent (Brunei Defence Council, 1974).

Only from April to May 1974 did the Brunei Government realise that PRB made Limbang their operational centre for Brunei. British officers have investigated that there were two organisations with full support from the office of the Chief Minister of Sarawak during its activity in Limbang which was also comprising PRB members and former member of TNKU (Brunei Security Report, 1974). Limbang's role became even stronger when nine families from the village of Lumapas, Brunei that were former detainees of Brunei's rebel in a total of 89 people fled to Limbang on 11 May 1974 (The Star, 1974). They fled due to rumours spreading that Brunei's police would be arresting former PRB members in those villages. However, Brunei's police believed that the villagers' movement was related to an effort joining all freedom advisors to free Brunei in an attempt centralised in Limbang (BHC Brunei, 1974a).

Due to Rahman Ya'kub's attacks on Sir Omar Ali through mass media and radio, Brunei's Police saw that as part of war psychology's tactic to move more former PRB detainees in Brunei to get them to support the efforts of the PRB in Malaysia. Moffatt labelled Rahman Ya'kub as an individual who supported violent activities involving former refugees of TNKU. Since the mid of May 1974, PRB campaigns started to involve in the distribution of pamphlets in Brunei (Moffatt, 1974a). Pamphlets and campaign materials were smuggled to Brunei from border paths, on the road and also along the river, to be sent to PRB supporters before it was distributed in Brunei. Support and help by Rahman Ya'kub towards PRB actually overtook the Limbang's issue, which was claimed by Seri Begawan. However, Brunei's freedom issue and Sir Omar Ali's position haunted by British's colonialism had serious impacts and will lead to a longer tension between the two countries (FCO, 1974).

Based on intelligence information from the Brunei Police, there was a meeting held on 31 May 1974 involving Rahman Ya'kub, Wan Hashim (Resident of Limbang), Yassin Affendi and two more PRB detainees in Malaysia (British High Commissioner in Brunei, 3 1974). The meeting's outcome was to reform PRB to claim freedom from British and continuous offensive actions towards Sir Omar Ali. This was seen by the British Advisors to have a serious effect on Brunei's safety. 
As a result of a meeting held in Miri on 31 May 1974, British officers had begun to take actions to intervene through the British High Commissioner Office in Kuala Lumpur. British Government wanted the Malaysian Government to intervene in handling issues of PRB and the tensed-relationship of SarawakBrunei that has started involving safety issues. However, the initial efforts of BHC in Malaysia were not fully successful as at the same time, Sir Omar Ali was continuously attacking and provoking Malaysia. The Malaysian Government admitted that it was not easy to control Rahman Ya'kub's activities due too many of his actions in Sarawak is based on internal political affairs of Sarawak (Norris, 1974a).

On 22 June 1974, Sir Omar Ali's worries worsened when another 22 more Brunei's students that were studying in Maktab Sultan Omar Ali Saifuddin (SOAS) fled to Limbang across the river. The students were involved with the distribution of pamphlets to gain support from villagers of Brunei (FEER, 1974). According to these students, they were campaigning to claim freedom so that the British Government would leave Brunei and freedom would be granted to Brunei (Maimunah Yusuf, 1974).

In the PRB election held on 17 June 1974 in Kuala Lumpur, A.M. Azahari was chosen again as a Leader. Being reappointed as the leader of PRB, A.M. Azahari gave a warning to Sir Omar Ali and the British Government. Even though PRB was still banned in Brunei, PRB supporters comprising TNKU members were in Miri and Limbang, Sarawak. British Officers witnessed Rahman Ya'kub's great support to the movement and activities by PRB detainees and TNKU in Sarawak, worrying that it would worsen and affect Brunei's safety. With the involvement of Azahari in PRB activities in Malaysia, the British Officers once again tried to get the Malaysian government's guarantee to block all political activities by the PRB and to avoid any fiery comments given by Rahman Ya'kub towards Sir Omar Ali (BHC Kuala Lumpur, 1974a). At the same time, the Malaysian government hoped that the British government would be able to control Sir Omar Ali's action on issues regarding Limbang.

Due to being pressured by PRB activities in Limbang's border, Brunei's Police suggested arresting all PRB detainees that were campaigning actively in Limbang or Lawas. These suggestions were rejected by J.W. Moffatt, who said that it was not rational and logical when Brunei was under pressure by AMNESTY and the UN regarding the 1962 prisoners alignment with Brunei issue on claiming freedom.

Since late 1975, the British Advisors saw Malaysia not only using PRB as a political tool, but at the same time, PRB too is using the Malaysian Government in order to achieve political purposes for them in Brunei. Sir Omar Ali's refusal 
to make changes in political freedom and the Constitution of Brunei became a motivation for PRB's activities. Sir Omar Ali is being surrounded by "the palace clique" and refused to approach Brunei's citizens to offer alternatives choices other than PRB to guard his position in Brunei (Bevan, 1975). Coster believed that Sir Omar Ali had to offer something to the people of Brunei to reduce PRB tensions in Brunei.

During the second discussion between Tan Sri Zaiton and British's representative in Kuala Lumpur, once again the security issue in Brunei was brought to attention. British's officers question Malaysia's action in using PRB and TNKU that was seen endangering the safety of Brunei and the position of British. Rahman Ya'kub's action to help PRB and TNKU was thought as intervening directly in Brunei's internal affairs (BHC Kuala Lumpur, 1974b). Once again, Tan Sri Zaiton highlighted that the Malaysian Government has never support on any subversive's activities used on the Brunei Government. The Malaysian Government's opinion was that Brunei would only be able to solve their issue once Sir Omar Ali stopped intervening in internal affairs of Sarawak in Limbang. Malaysian Government also understood the roles of British's Officers in Brunei and their limitation of powers in handling the foreign affairs in Brunei. However, Tan Sri Zaiton reminds the British Officers that the Malaysian Government, too, are facing difficulties in controlling the Chief Minister of Sabah and Sarawak due to political factors. Failure of consultation with Tan Sri Zaiton has led the British Officers to decide to intervene in order to avoid worsening relations by stating Malaysia's willingness to cooperation provided the Limbang claim is not pressed (de Courcy-Ireland, 1974a).

As the Limbang issue was selling like hot cakes, the police found recorded cassettes by Azahari in Brunei containing a call upon Brunei's citizens to support PRB's fight and promising his loyalty and also PRB's loyalty to Sir Omar Ali and Brunei's Sultan. Azahari blamed the British government as having poisoned Sir Omar Ali's way of thinking to reject freedom and organising an election in Brunei (A.M. Azahari, 1974).

The PRB detainees were not only allowed to move freely; they were also involved in political work in Sarawak's elections. This situation opposed the promises made by Ghazali Shafie during the granting of the political asylum to PRB detainees (Gautrey, 1974b). Evidence found on subversive activity sponsored by the Sarawak Government was not only able to rise the safety issues in Brunei. There was also a fear that this would affect the relationship between the British Government and Malaysia. British Advisors sees Sir Omar Ali's action in evoking the Limbang's issue will not only raise political and administration issues, meanwhile dragging the British Government in Brunei's security issue. 
Therefore, an effort to talk to Sir Omar Ali was done by P. Gautrey, Coster and Pehin Isa Aziz (Sir Omar Ali's advisor) so that it may be able to change Brunei's Government constitutional especially in regards to the political prisoner issue in 1962, hence to reform the Constitutional of Brunei. Changes are hope that it would solve the unsatisfied feelings of the PRB former detainees and also Brunei's students who came back from overseas (Brunei State of Security Assessment, 1974). Students who came back from the overseas review the political freedom in Brunei as very limited. Apart from that, there were hateful sentiments among the Malay officers in the government sector and the army, who had no chances to step ahead in their career to a higher level as citizens of Brunei. This was seen by the British Officers as a potential threat to the Brunei Government and embodying chances to be manipulated by PRB activists to develop the spirit of revolution to claim freedom for Brunei from the colonialism of the British. However, it was a failure since it was in the attention of Sir Omar Ali (Moffatt, 1974b).

The initial effort made by PRB to give tension towards Brunei has shown success when the early suggestion brought by PRB members to UN has gotten supports from the majority of countries such as Africa and Iraq in 1974 (Hinchcliffe, 1973). This draft's approval worried Britain as it would bring the UN's representative to Brunei to investigate the freedom issue even though the decision was in the Sultan of Brunei's hand. If the Sultan of Brunei barred the arrival of the UN's officers, the British Government would be ashamed internationally due to them in charge of the foreign affairs of Brunei. On that base, the British Government has tried to put aside Brunei issue from becoming an agenda in Committee of 24, UN. The step to get help from Malaysia has not gotten any support with a reason that Malaysia worried the act will affect Malaysia's image that was seen conservatives especially when it comes to colonialism issue (Norris, 1974b).

Success in bringing the Brunei issue as part of the resolution in the UN had given confidence to the majority of PRB supporters that Brunei would gain their freedom shortly. This situation has raised Azahari's image amongst Brunei's citizens. Hence, a visit by Azahari to Limbang on 1 September 1975 has come to attention especially not only from Brunei's citizens but also people from Sipitang, Sabah, and Sibuti in Sarawak. Azahari promised freedom for Brunei entirely out from Brunei's colonialism, and his campaign gave trust to Brunei's citizen that a political change will happen in Brunei (Moffatt, 1975a). In this visit, Azahari has displayed a film's visual regarding PRB efforts in UN.

Success in bringing up the Brunei issue to the Committee of 24 in UN worries the Sultan to maintain his political "survival." The effects led Sir Omar 
Ali in again trying to purchase military equipment on a big scale comprising the air defence system, artillery and tanks (Beevam, 1975). However, this step was not needed by the British officers in Brunei because it was seen as too massive and out of scale with Brunei's needs. For the British Government, the threat to the Brunei Government fid not only come from other countries or Malaysia but more in terms of the internal affairs of Brunei (SWPD, 1976a).

On 13 November 1975, Azahari has pleaded to the Fourth Committee UN with sponsorship from the Malaysian Government (Reece, 2008), and was supported by Australia, Philippines and Indonesia so that their election is free and will be held as fast as possible in Brunei. Azahari's plead approved by the UN through resolution 3424 (XXX) on 8 December 1975 (3424 (XXX), 1975). The UN approved the same resolution in 1976 (Question of Brunei, 1976) and 1977 (Question of Brunei, 1977); these were, however, rejected by the Brunei Government. The British Government supported efforts to revive democratic practices and elections in Brunei, but they have no authority over internal affairs which had been handed to the Sultan of Brunei through the Anglo-Brunei Agreement 1971. Sir Omar Ali also worried about the existence of free elections and democracy will marginalise his power in Brunei.

\section{PRB Failure and Ended the Struggle}

Increased PRB activity lead British Advisors in Brunei to suggest that the Malaysian Government remove all PRB detainees from Sarawak in order to decrease any prevocational activities in Limbang and Brunei's border (BHC Brunei, 1974b). Another negotiation was held by the Malaysian Ministry of Foreign Affairs (Wisma Putra) and the British's Commissioner in Malaysia by the end of November 1974. However, Wisma Putra once again denied the accusations involving Rahman Ya'kub and the validity of the meeting's report on 31 May 1974 in Miri. In the same meeting, Zaiton brought up the issue of foreign funding from Brunei's palace in Sarawak's election as an acute intervention by the Malaysian Government. Zaiton saw the whole tension episode between Malaysia and Brunei due to Sir Omar Ali's claim towards Limbang District (Norris, 1974c). Through this meeting, the British Government pleaded that the support and aid to PRB be reduced in order to lessen tensions between the two governments. The British Officers were hoping that the Malaysian Government to not use any more violence by sponsoring any subversives' activities to solve the problem with Brunei's Government (de Courcy-Ireland, 1974b).

Failure to secure a guarantee from Tan Sri Zaiton has led to the British Government to once again sending E. Norris, British High Commissioner to Malaysia to discuss with Tun Razak. In this official discussion, E. Norris 
conveyed their concern about the help and political activities organised by the PRB in Malaysia that could affect the safety of Brunei. E. Norris pleaded for the Malaysian Government to stop any kinds of help and to bring all PRB members to West Malaysia (Norris, 1974d). Despite Tun Razak's denial in the involvement of Rahman Ya'kub's in all the activities, he is still providing a guarantee that he will be monitoring PRB's movement. For Tun Razak, the issue of controlling and monitoring Rahman Ya'kub's actions was not an easy issue to address, and it was seen as the same to how difficult it was for British Officers to control Sir Omar Ali.

From the end of 1974 until August 1975, the provocations in Limbang's border decreased. Yassin Effendy was moved from Limbang to Kuching and was not allowed to leave Sarawak. PRB members also prohibited from being involved in any political activity in Malaysia (Moffatt, 1975b). Apart from that, the Brunei Governments has officially launched campaigns of the war of nerves through Psyops since early 1975. The invasion and capturing of PRB members, especially in Belait and Seria in Brunei have managed to weaken PRB's movement from Brunei. In early January 1975, PRB received a great wakeup call when Awangku Hamzah (an individual who helped escaping PRB detainees from Berakas Detention Camp) defected from PRB. In a newspaper's conference, Awangku Hamzah has accused Zaini Ahmad, Yasin Affendy and other PRB members that were used by Foreign Government (Malaysia) to ruin Brunei's harmony (Awangku Hamzah, 1975). In between January and August 1975, PRB activities in Malaysia were seen to be decreasing due to many PRB leaders moving out of the country to get support in order to bring PRB resolutions in Committee of 24, United Nations on 15 July 1975.

Apart from that, Brunei's Police conducted spying of each conversation in between the PRB detainees and Rahman Ya'kub (Moffatt, 1975c). Hence, Brunei's Police were able to overcome efficiently by arresting PRB's contacts in Brunei. Arresting PRB members in Brunei has weakened many PRB campaigns in Brunei. When there was an increment of the Communist movement in Perak, the Malaysian Government has started to move part of Intelligent Unit from RASCOM Sri Aman to Perak. This move has successfully distracted the focus of the Malaysian Government from PRB issues to the Communist issue. This situation has helped to the rising of successfulness of Psyops in Brunei.

Approaching the end of 1975, PRB was seen starting to have an internal affair of splitting, when there was an argument between Azahari and Zaini regarding execution in Brunei. According to Zaini, Azahari is prone to choose a violent approach due to not feeling sure towards British's way of preferring 
discussions and dialogues. Meanwhile, Zaini prefers a harmonious approach without violence.

Despite an argument in between Zaini and Azahari, a meeting of PRB Committee on 12 January 1976 gave a full mandate to Azahari's leadership to lead PRB. PRB firmly stated that they would fight for Brunei's freedom through discussions and democracy except "all avenues had been closed" (New Straits Times, 1976). Zaini's allegations towards Azahari and his tactics to gain freedom through violence denied by PRB members (Crosbie, 1978). The truth is that the PRB members do not prefer Zaini's act that promoting his violence-free and educated as well as a highly tolerated person to gain trust from the Sultan of Brunei. PRB members consider Zaini as being selfish hence putting aside PRB. Even though the arguments in PRB was seen as positive to Sir Omar Ali, the pressure by the British Government to evacuate all Gurkhas Army in Brunei has started to worry him. If all the Gurkhas Army were evacuated from Brunei, hence Sultan's position will be exposed to threat due to the failure to provide political freedom to the citizens of Brunei. For Zaini, only general elections that are fair and square will be able to help protect the Sultans and the Government of Brunei from subversive elements outside of Brunei (Zaini, 1976). PRB's fight has gotten complicated due to the passing of Tun Razak on $16^{\text {th }}$ January 1976.

The British Government saw issues of help and military training in the Middle East as really worrying. British are afraid that any elements brought in by the Middle East will affect the militant element into PRB. Any militant's influence will not only be seen as endangering Brunei's Government but also to the whole South East Asia. In addition to Zaini's being brushed off from PRB, the British Government is afraid that PRB and Azahari will be prone to using violence tactics in order to achieve their targets. For the purpose, the Malaysian Government had been requested to be constructive in any business related to Brunei and was asked to closely monitor the PRB members' activities (SWPD, 1976b). Reaching the end of March 1976, the Malaysian Government is seen to take careful initiatives on PRB activities in Malaysia (Kidds, 1976a). The monitoring by the Malaysian Government has made PRB delaying their representatives to the Middle East to further their studies in addition to undergoing military training. This delay was related to the effect of the changes in the Government's policy by Hussein Onn that refused Malaysia in being campaign centres for PRB towards Brunei.

British Officers are sure that with the PRB students off to Libya, it is not only to further their studies but more to undergo military training. In addition, British Officers are sure that the PRB students going to Libya are unknown to Hussein Onn (Draft Security Report, 1976). With the help of additional 
information from spies which was different that official information by Malaysian Government making space for a question to brought up whether on the year of 1976, PRB has still gotten support from the Malaysian Government, or there were only a few supports from Officers in Malaysia. The effect was seen that since the mid-year of 1976, Azahari was not allowed to enter Malaysia. Apart from that, Malaysia was seen to minimise all kind of help given to PRB in Kuala Lumpur.

Based on the intelligence's information by British, it is clear that the students sent to Libya on 21 June 1976 by PRB were to undergo pre-military training that was as a preparation to face the violence when the negotiations for independent and political freedom in Brunei meeting the dead end (Draft Security Report, 1976). This information is also seen to be giving a huge chance to the British Government to marginalised PRB roles from being too active in Malaysia (Kidds, 1976b).

Due to the information received by the British Government, the investigation had been made by the Malaysian Police, and it is clear that 32 PRB members who went to Libya in 1976 were undergoing the military training. Hence, Hussein Onn has started to take actions such as to minimalise all kinds of help and support by the Malaysian Government. Besides that, PRB's activity in Malaysia will be monitor, and to stop all PRB-Libya's relationship at the end of 1976 (Liefer, 1978). PRB members, too, are not allowed to be involved in any antiBritish Government's activities or Brunei during their presence in Malaysia (BHC Kuala Lumpur, 1977). However, the Malaysian Government did not take any actions against PRB members because they do not commit any crime in Malaysia. The action taken by Hussein Onn has started to gain trust from the Brunei Government towards the Malaysian Government. This approach was seen as different that Tun Razak's approach in managing this issue regarding the PRB detainers. Hussein Onn is also saw as less interested in sponsoring any PRB movements which caused the PRB activities to be decreasing. Hussein Onn's act that leads to the restoration of the relationship with Brunei has made PRB to be alienated. The last time Malaysia supported the resolution brought by PRB to the UN was in 1977. Apart from the changes of Malaysian Government since 1977, the Sarawak's State Government had shown changes when Rahman Yaakub started bridging the two-way relationship with Brunei (New Straits Times, 1977). The recovery of relationship in between Sarawak, Sabah and Brunei were started through a soccer match, "Borneo Cup" on 18 to 21 June 1977 that was seen as one of the early moves to get the three regions close to each other (Pelita Brunei, 1977). Starting 1978, PRB does not anymore gets any supports from Malaysian 
Government when Malaysia sees the need for support to be given to Brunei's Government who would gain independence from Britain.

The changes by the Malaysian Government were even more significant when there was a meeting held in between Hussein Onn with Sir Omar Ali and Sultan Hassannal Bolkiah in London on June 1977 (BHC Kuala Lumpur, 1980). Ghazali Shafie considers this as a good sign as a catalyst for Brunei to achieve their independent. Positives developments since mid of 1977 have become even more robust through "Polo Diplomacy" (Davidson, 1977). Polo Diplomacy and offers of help from the Malaysian Government to the officers, educations and Brunei's military training was seen to be a contributing factor to the recovery of Malaysia-Brunei's relation from the tense phase to a new recovery phase. Administrator's act during Hussein Onn's administration gave chances to the Brunei Government to slowly change their perceptions towards Malaysia (East Asian Analysis, 1983). Even though the fact that the changes were pretty slow, but it has successfully subdued any tension in their strategic relationship.

Following the meeting in between Hussein Onn and Seri Begawan in London on June 1977, it has led to another more in-depth discussion in between Hussein Onn and President Suharto in Labuan on the 17 to 18 May 1978. Through this meeting, Indonesia gave a guarantee of support for Brunei to achieve independence. Besides, Indonesia would also take action to prevent Azahari from giving any political statements towards the Government of Brunei (U.S. Embassy Kuala Lumpur, 1978). Hussein Onn, in the same meeting, gave his commitment to not interfering in any internal affairs of Brunei. Malaysia and Indonesia have offered Brunei to join ASEAN when Brunei has gained their independence later on (Thambipillai, 1982).

Approaching the initial consultations between Brunei and Britain in June 1978, the British Government has pronounced there were initiatives to give a full independent to Brunei. An agreement was accomplished to let the Gurkhas Army in Brunei until September 1983 (The Straits Times, 1978). Hussein Onn has shown commitment to execute Malaysia's exceptional policy by maintaining the principle of respecting harmony in togetherness, respecting the sovereignty of territories, and not aggressive and no interference in internal affairs on a state and to maintain peace (Means, 1991: 76-78).

An official agreement was signed on 8 January 1979 to replace the Agreement of Anglo-Brunei 1971. This act is one of the initial efforts towards the independence of Brunei in 1984. Behind the restoration of the relationship between Brunei and Malaysia, PRB had been alienated continuously and slammed on Britain's act that was putting aside UN's resolution (Watan, 1979) 
even though PRB has always been welcoming to British's act to let Brunei achieve their independence.

Through the 1979's agreement, the British Government had been committed to fulfilling the promise of Brunei's independent at the end of the year 1984. In this agreement, the Brunei Government is given a period of five years to make preparations prior to independent. As one of the early steps to fix the relationship of Brunei and Malaysia's officers, cooperation with Australia was made to postpone Brunei's issues from being discussed in the Fourth Committee's conference in UN on December 1978. Brunei issue will only be discussed upon on 9 December 1983 in tandem with Brunei's application to become a new member of the United Nations (Decolonization No. 20. 1983).

\section{Conclusion}

There were huge differences in managing issues pertaining to PRB and Brunei between the Malaysian Government and British Government. Malaysia gave help on two main bases, which was to distract attention from Limbang's issue, and to prevent PRB from being affected by communists. Even though Malaysia's help to PRB has put British's position in danger as they received pressure from PRB in Limbang's border has increased the anti-Brunei Government's activities. Malaysia, on the other hand, saw Brunei's position as being unable to gain their independence, as they were fragile, and that will automatically put Malaysia's safety, especially in Sarawak and Sabah, to be endangered. Moreover, Malaysia is worried about Brunei's free entity that will convey the inspiration to the separatist's movement to be even more active in Sarawak and Sabah (Weatherbee, 1983). The Malaysian Government saw the monarchical system as no longer suitable based on the situation after the World War II and hoped that Brunei Government would be able to leave the power to administrate to the hands of the citizens through elections. However, to the Brunei Government, it was like seeing Malaysia as interfering into the internal affairs of Brunei. Despite UN and Malaysia witnessing the need for an election in Brunei, the British Government does not own any power onto the internal affairs of Brunei that was fully on Brunei's government. Lastly, Brunei's readiness to achieve independence on 1 January 1984 has successfully ended all of PRB's struggles since 1973.

\section{Acknowledgement}

The study is funded by the Federal Training Prize-Full Scholarship on Extending the Study at the level of Doctor of Philosophy, Malaysian Ministry of Education (September 2016-August 2019). 


\section{References}

3424 (XXX). (1975). Question of Brunei. 8 December, [1 May 2018 http://www.un.org].

A.M. Azahari. (1974). Speech transcript. 20 August, FCO 24/1952.

Awangku Hamzah. (1975). Press Report, 1 April, FCO 24/2089.

Bernama. (1974, June 19).

Bevan, L. (1975). SWPD to P.L. O'Keefe, FCO, 6 October, FCO 24/2089.

BHC Brunei. (1973a). to FCO, 26 July, FCO 24/1673.

BHC Brunei. (1973b). to FCO, 4 August, FCO 24/1673.

BHC Brunei. (1974a). to FCO, 18 May, FCO 24/1951.

BHC Brunei. (1974b). to BHC Kuala Lumpur, 14 September 1974, FCO 24/1975.

BHC Kuala Lumpur. (1973a). to FCO, 20 July, FCO 24/1673.

BHC Kuala Lumpur. (1973b). to FCO, 14 December, FCO 24/1675.

BHC Kuala Lumpur. (1974a). to FCO, 5 July, FCO 24/1951.

BHC Kuala Lumpur. (1974b). to FCO, 29 July, FCO 24/1952.

BHC Kuala Lumpur. (1977). to SEAD, 4 January, FCO 15/2272.

BHC Kuala Lumpur. (1980). Malaysia and Brunei Relations to Secretary of State for Foreign and Commonwealth Affairs, 5 November, FCO 15/2743.

Boldt, S.M. (1973a). BHC Kuala Lumpur to W.K. Slatcher, SWPD, 3 September, FCO 24/1673.

Brunei Defence Council. (1974). Report to J.K. Hickman SWPD, 5 March, FCO 24/1951.

Brunei Security Report. (1973). Report on the security situation in Brunei State for the period $1^{\text {st }}$ September 1973 to $8^{\text {th }}$ October 1973, FCO 24/1685.

Brunei Security Report. (1974). Report on the Security situation in Brunei state for the period $9^{\text {th }}$ April to $4^{\text {th }}$ May 1974, FCO 24/1951.

Brunei State of Security Assessment. (1974). 12 October, FCO 24/1953.

Crosbie, A. J. (1978). Brunei the constraints of a small state, Southeast Asian Affairs.

Davidson, J. A. (1977). BHC Brunei to SEAD FCO, 3 October, FCO 15/2272.

de Courcy-Ireland, P. G. (1974a). SWPD to Wilford, SEAD, 5 August, FCO 24/1969.

de Courcy-Ireland, P. G. (1974b). SWPD to Wilford, FCO, 22 November, FCO 24/1953.

Decolonisation No. 20. (1983). Brunei-December 1983, http://www.un.org [30 October 2018]

Draft Security Report. (1976). Security situation in Brunei for the period 26 May to 21 June 1976, FCO 24/2262.

Far Eastern Economic Review. (1973, August 27). The Breaking Point. 
Far Eastern Economic Review. (1974, June 24). Reviving the revolt.

FCO. (1973a). Meeting between the Tan Sri Ghazali Shafie, Parliamentary Under-

Secretary the Malaysian Minister of Home Affairs and A.H.F. Royle, Foreign and Commonwealth Office, FCO, 11 September 1973, FCO 24/1679.

FCO. (1973b). to BHC Kuala Lumpur, 20 July, FCO 24/1673.

FCO. (1973c). to BHC Brunei, 24 July, FCO 24/1673.

FCO. (1974). to BHC Brunei, 11 June, FCO 24/1951.

Flower, R. P. (1973). SWPD, to J.K. Hickman, SWPD, 17 August, FCO 24/1673.

Gautrey, P. (1973). BHC Brunei to Malaysian Government, 14 July, FCO 24/1673.

Gautrey, P. (1974a). BHC Brunei to J.K. Hickman, FCO, 7 May, FCO 24/1951.

Gautrey, P. (1974b). BHC Brunei to FCO, 9 September, FCO 24/1952.

Harun Abdul Majid. (2007). Rebellion in Brunei: The 1962 Revolt, Imperialism,

Confrontation and Oil. London: I.B. Tauris.

Hickman, J. K. (1973a). SWPD to A. Royle, 24 August, FCO 24/1679.

Hickman, J. K. (1973b). SWPD to A. Royle, 21 September, FCO 24/1673.

Hickman, J. K. (1973c). SWPD to A. Royle, 12 November, FCO 24/1673.

Hickman, J. K. (1973d). SWPD to A. Royle, 4 December, FCO 24/1685.

Hinchcliffe, P.R.M. (1973). United Kingdom Mission to the United Nations to T.A.H. Solesby, FCO, 6 December 1973, FCO 24/1677.

Jha, A. S. (2014). Social Research Methods. New Delhi: McGraw Hill Education (India) Private Limited.

Johnston, J. B. (1973a). BHC Kuala Lumpur to SWPD, 22 August, FCO 24/1679.

Johnston, J. B. (1973b). BHC Kuala Lumpur to K.M. Willford, FCO, 4 September, FCO 24/1679.

Johnston, J. B. (1973c). BHC Kuala Lumpur to J.K. Hickman, SWPD, 28 December, FCO 24/1675.

Kidds, E. R. G. (1976a). BHC Brunei, File Note: Political Intelligence, 30 March, FCO 24/2262.

Kidds, E. R. G. (1976b). File Note: Political Intelligence, 20 July, FCO 24/2262.

Liefer, M. (1978). Decolonisation and International Status, the Experience of Brunei. International Affairs, 54(2), 1 April: 248-249.

Mackie, J.A.C. (1974). Konfrontasi: the Indonesia-Malaysia dispute, 1963-1966. Kuala Lumpur: Oxford University Press.

Mahmud Morshidi bin Othman. (2018). Interview in Kuala Lumpur, 7 February.

Maimunah Yusuf. (1974). 22 Orang pelajar Brunei lari ke sini. Utusan Malaysia, 18 November: 1.

Means, G. P. (1991). Malaysian Politics: The Second Generation. Singapore: Oxford University Press: 76-78. 
Mohamed Bolkiah. (2007). Remember, Remember...The 8Th Of December. Brunei: Brunei Press.

Moffatt, J. W. (1973a). BHC Brunei to Coster, 20 November, FCO 24/1675.

Moffatt, J. W. (1973b). BHC Brunei to J. Johnstons, BHC Kuala Lumpur, 22 November, FCO 24/1675.

Moffatt, J. W. (1974a). BHC Brunei Minutes to Coster, Head of Special Branch Brunei, 18 May 1974, FCO 24/1951.

Moffatt, J. W. (1974b). BHC Brunei, DEC meeting notes, 10 September, FCO 24/1952.

Moffatt, J. W. (1975a). BHC Brunei to R.P. Flower, SWPD, 13 January, FCO 24/2089.

Moffatt, J. W. (1975b). Internal Security: Brunei, 22 April, FCO 24/2089.

Moffatt, J. W. (1975c). BHC Brunei, Files Note: Political Intelligence, 24 September, FCO 24/2089.

Nani Suryani binti Abu Bakar. (2016). Brunei relations with Malaysia: 1963-1983' in Brunei Merdeka: Kumpulan Artikel Sempena Memperingati Sambutan 30 tahun Hari Kebangsaan Negara Brunei Darussalam, Haji Awang Asbol bin Mail, Haji Awang Mohd. Yusop bin Haji Awang Damit and Awang Haji Rosli bin Haji Ampal (ed.), Bandar Seri Begawan: Yayasan Sultan Haji Hassanal Bolkiah.

New Straits Times. (1976, January 13). Azahari: Parti Rakyat's vote of confidence.

New Straits Times. (1977, March 28). PBB hails Brunei move for better ties. 28 March.

Norizan Kadir. (2017). Pembentukan Malaysia dan Rancangan Alternatif Filipina Menuntut Sabah Pasca Kegagalan Misi Irrendentism Filipina, 1963-1965. Jebat: Malaysian Journal of History, Politics E Strategic Studies, Vol. 44 (1) (July 2017).

Norris, E. (1974a). BHC Kuala Lumpur to K.M. Wilford, FCO, 18 Jun, FCO 24/1951.

Norris, E. (1974b). BHC Kuala Lumpur to FCO, 29 July, FCO 24/1952.

Norris, E. (1974c). BHC Kuala Lumpur to K.M. Willford, FCO, 11 November, FCO 24/1953.

Norris, E. (1974d). BHC Brunei to KM. Wilford, 28 November, FCO 24/1953.

Osman Latif. (2017). Interview in Kuala Lumpur, 17 May.

Poulgrain, G. (2014). The Genesis of Konfrontasi: Malaysia, Brunei and Indonesia 1945-1965. Petaling Jaya: Strategic Information and Research Development Centre.

Pelita Brunei. (1977, June 15). Piala Borneo siri baru. 
Question of Brunei. (1976). A/RES/31/56. 1 December, [3 May 2018 http://www.un.org].

Question of Brunei. (1977). A/RES/32/27. 28 November, [5 May 2018 http://www.un.org].

Reece, B. (2008). An Interview with Dr. Hj Zaini Ahmad, Kuala Lumpur, 1985, in C. Sather (Ed.), Borneo Research Bulletin, Vol. 39: 91-92.

Said Haji Mohidin. (2010). Pemberontakan di Brunei 1962: Sabah dan Sarawak Terkena Tempiasnya, Limbang: Penerbit Haji Said bin Haji Mohidin.

Suara Rakyat. (1957). Akhbar Parti Rakyat Brunei.

SWPD. (1973). Note: Brunei/Malaysian Relations, 7 September, FCO 24/1679.

SWPD. (1976a). Talks with Sultan of Brunei, 2 January, FCO 24/2102.

SWPD. (1976b). Record discussions between Australia and New Zealand, 24 February, FCO 15/2272.

Thambipillai, Pushpa. (1982). Brunei in ASEAN: The Viable Choice?, Southeast Asian Affairs.

The Star. (1974, May 20). 89 flee Brunei families cross to Limbang after visits by police.

The Straits Times. (1978, July 1). Gurkhas will remain in Brunei till '83.

U.S. Embassy Kuala Lumpur. (1978). Telegram: Malaysian Indonesian bilateral talks at Labuan, kepada Secretary of State, Washington D.C., 23 May, 1978KUALA 04417, D780216-0907 https://aad.archives.gov [20 september 2018].

Watan. (1979, Januari 9). Parti Rakyat alu2kan perjanjian dan peranan Sultan Brunei, sikap British diselar.

Weatherbee, D. E. 1983. (1983). Brunei: The ASEAN Connection. Asian Survey, 23(6): 728.

Zaini bin Ahmad. (1989). Pertumbuhan Nasionalisme di Brunei (1939-1962). Kuala Lumpur: ZR Publications. 